\title{
Optimalisasi Persediaan Bahan Baku Kemasan Air Mineral Menggunakan Model Economic Order Quantity (EOQ)
}

\author{
Nonny Helena Maria Simbolon ${ }^{1, *}$, Sunarsih $^{1}$, Kartono $^{1}$ \\ ${ }^{1}$ Departemen Matematika, Fakultas Sains dan Matematika, Universitas Diponegoro, \\ Semarang, Jawa Tengah, Indonesia \\ *email korespondensi: nonnyhelena@students.undip.ac.id
}

Received : 11 Juni 2021; Revised : 7 Juli 2021; Accepted : 24 Agustus 2021; Published : 19 September 2021

ABSTRAK

Persediaan bahan baku yang optimal pastinya sangat dibutuhkan oleh setiap perusahaan. Perusahaan akan melakukan berbagai persiapan yang matang pada proses produksi untuk memastikan kelancaran produksi setiap saatnya. Bahan baku adalah salah satu komponen penting dalam persiapan produksi. Persediaan bahan baku yang optimal akan memperlancar persiapan proses produksi. CV Tirta Makmur merupakan perusahaan yang memproduksi Air Minum Dalam Kemasan (AMDK), CV Tirta Makmur juga sangat memperhatikan permasalahan persediaan yang optimal. Perusahaan memiliki kebijakan tersendiri untuk menghadapi permasalahan persediaan yang optimal. Penelitian ini bertujuan untuk melakukan pengoptimalan dalam persediaan bahan baku cup $120 \mathrm{ml}$ di CV Tirta Makmur, dimana cup $120 \mathrm{ml}$ merupakan produk yang memiliki jumlah permintaan paling banyak. Pada penelitian ini akan dilakukan perhitungan dengan menggunakan metode EOQ (Economic Order Quantity) untuk mencari jumlah pemesanan yang optimal terhadap bahan baku cup $120 \mathrm{ml}$. Hasil yang didapatkan dari perhitungan dengan menggunakan metode EOQ akan dibandingkan dengan perhitungan kebijakan perusahaan. Hasil yang diperoleh menunjukkan bahwa kebijakan yang digunakan oleh perusahaan selama ini masih kurang efektif untuk mengoptimalkan biaya pembelian bahan baku. Diharapkan dengan menggunakan metode EOQ sebagai perhitungan untuk mengoptimalkan persediaan bahan baku cup $120 \mathrm{ml}$ dapat menjadi masukan yang baik bagi perusahaan dalam menghadapi permasalahan persediaan dan dapat mengantisipasi terjadinya kerugian maupun kekurangan stok saat dilakukan produksi.

Kata-kata kunci: biaya pembelian; metode EOQ; pemesanan optimal; persediaan bahan baku

\section{PENDAHULUAN}

Persediaan bahan baku yang optimal merupakan salah satu upaya yang dapat membantu perusahaan dalam melakukan proses produksi yang optimal. Menurut Santoso (2009) setiap perusahaan, baik perusahaan jasa maupun perusahaan manufaktur, selalu memerlukan persediaan. Menurut Sofyan (2017) perusahaan akan melakukan berbagai persiapan yang matang pada proses produksi untuk memastikan kelancaran produksi setiap saatnya. Bahan baku merupakan komponen yang paling dibutuhkan dalam persiapan produksi pada tiap perusahaan. Banyaknya permintaan yang terkadang tidak dapat diprediksi dengan baik, dapat menyebabkan persediaan bahan baku tidak stabil, terkadang permintaan terlalu banyak maupun terlalu sedikit sehingga menyebabkan persediaan bahan baku menipis maupun melebihi kapasitas penyimpanan. Terjadinya persediaan bahan baku yang menipis maupun bahan baku yang melebihi kapasitas penyimpanan dapat menyebabkan kerugian pada suatu perusahaan, bahkan dapat menghambat berjalannya proses produksi pada perusahaan tersebut Kurniawati (2018). Karena ini diperlukan usaha untuk menanggulangi terjadinya kerugian yang diakibatkan oleh persediaan bahan baku yang tidak optimal. Setiap perusahaaan yang tumbuh dan berkembang pastinya memerlukan pengendalian persediaan bahan baku. Salah satu usaha yang dapat dilakukan yaitu menentukan kebijakan persediaan bahan baku yang tepat, dalam arti tidak mengganggu proses produksi, dengan menggunakan metode EOQ (Economic Order Quantity) (Kristyaningrum et al., 2018).

Metode EOQ telah banyak digunakan sebagai salah satu metode dalam menyelesaikan permasalahan bagaimana cara mengendalikan persediaan bahan baku sehingga menghasilkan total biaya pengadaan bahan baku yang lebih ekonomis. Menurut Vikramul Ainum Na'im (2016) metode EOQ merupakan teknik pengendalian persediaan yang klasik atau tertua dan paling sederhana. Beberapa penelitian telah dilakukan dengan menggunakan metode EOQ, sebagai contoh, penulis-penulis yang telah melakukan penelitian adalah 
sebagai berikut : Andari \& Solahuddin (2019), Lahu et al. (2017), Putri et al. (2020), dan Yaqin (2018). Dengan menggunakan metode EOQ, ini bisa didapatkan berapa jumlah pemesanan persediaan bahan baku yang optimal setiap kali dilakukan pemesanan bahan baku pengemas air mineral, bagaimana siklus pengadaan persediaan bahan baku pengemas air mineral dalam satu periode, berapa total biaya pemesanan yang dikeluarkan setiap kali melakukan pemesanan, dan kapan CV Tirta Makmur harus melakukan pemesanan kembali Febilia (2016)

CV Tirta Makmur adalah sebuah perusahaan air mineral yang didirikan pada tahun 2004 yang hingga saat ini sudah sangat berkembang dengan pesat. CV Tirta Makmur menyediakan produk air mineral dalam berbagai jenis ukuran yang bervariasi. Bahan baku utama yang digunakan dalam proses produksi pada perusahaan ini adalah air yang bersumber dari mata air alami gunung Ungaran yang terletak di daerah Semarang selatan, sedangkan bahan baku pengemas dalam perusahaan ini antara lain cup, botol, galon, lid cup, tutup botol dan galon, kardus, dan pipet. Dengan berbagai jenis bahan baku pengemasan tersebut tentunya perusahaan membutuhkan pengoptimalan persediaan bahan baku yang tepat demi kelancaran produksi perusahaan.

Produk Pelangi cup $120 \mathrm{~mL}$ (mili Liter) merupakan produk yang memiliki jumlah permintaan terbanyak diantara seluruh produk AMDK Pelangi, sehingga menyebabkan jumlah persediaan yang besar. Hal penting bagi perusahaan yaitu untuk mengoptimalkan persediaan dan meminimalkan biaya pemesanan sehingga dapat memaksimalkan keuntungan. Tabel 1 menyajikan jumlah permintaan cup $120 \mathrm{~mL}$ pada April 2020 sampai April 2021.

Tabel 1. Modal Pembelian dan Persediaan Akhir CUP 120 mL Tahun 2020-2021

\begin{tabular}{llrrrrrr}
\hline \multirow{2}{*}{ No } & \multirow{2}{*}{ Bulan } & \multicolumn{2}{c}{ Pembelian } & \multicolumn{2}{c}{ Pemakaian } & \multicolumn{2}{c}{ Persediaan Akhir } \\
\cline { 3 - 8 } & & \multicolumn{1}{c}{ Pcs } & \multicolumn{1}{c}{ Rp } & \multicolumn{1}{c}{ Pcs } & \multicolumn{1}{c}{ Rp } & \multicolumn{1}{c}{ Pcs } & Rp \\
\hline $\mathbf{1}$ & Apr & 859.600 & 87.679 .200 & 1.980 .192 & 201.979 .584 & -1.120 .592 & -114.300 .384 \\
$\mathbf{2}$ & Mei & 4.114 .160 & 419.644 .320 & 3.728 .688 & 380.326 .176 & 385.472 & 39.318 .144 \\
$\mathbf{3}$ & Juni & 3.548 .240 & 361.920 .480 & 3.777 .216 & 385.276 .032 & -228.976 & -23.355 .552 \\
$\mathbf{4}$ & Juli & 1.360 .000 & 138.720 .000 & 1.431 .456 & 146.008 .512 & -71.456 & -7.288 .512 \\
$\mathbf{5}$ & Agus & 4.945 .080 & 504.398 .160 & 2.289 .360 & 233.514 .720 & 2.655 .720 & 270.883 .440 \\
$\mathbf{6}$ & Sept & 2.800 .000 & 285.600 .000 & 3.474 .240 & 354.372 .480 & -674.240 & -68.772 .480 \\
$\mathbf{7}$ & Okto & 4.802 .000 & 489.804 .000 & 3.595 .152 & 366.705 .504 & 1.206 .848 & 123.098 .496 \\
$\mathbf{8}$ & Nov & 2.744 .000 & 279.888 .000 & 3.628 .032 & 370.059 .264 & -884.032 & -90.171 .264 \\
$\mathbf{9}$ & Des & 2.503 .200 & 255.326 .400 & 2.764 .656 & 281.994 .912 & -261.456 & -26.668 .512 \\
$\mathbf{1 0}$ & Jan & 4.594 .000 & 468.588 .000 & 3.504 .144 & 357.422 .688 & 1.089 .856 & 111.165 .312 \\
$\mathbf{1 1}$ & Feb & 3.041 .000 & 310.182 .000 & 2.820 .672 & 287.708 .544 & 220.328 & 22.473 .456 \\
$\mathbf{1 2}$ & Mar & 4.482 .000 & 457.164 .000 & 5.048 .256 & 514.922 .112 & -566.256 & -57.758 .112 \\
& & 39.793 .280 & 4.058 .914 .560 & 38.042 .064 & 3.880 .290 .528 & 1.751 .216 & 178.624 .032 \\
\multicolumn{2}{c}{ Jumlah } & $3.316 .106,667$ & & 3.170 .172 & & $145.934,667$ & \\
\multicolumn{2}{c}{ Rata-rata } & & & & & & \\
\hline
\end{tabular}

Berdasarkan Tabel 1, ini terlihat ada beberapa periode yang menunjukkan perbedaan antara pembelian dan pemakaian bahan baku sehingga terkadang terjadi kekurangan stok maupun kelebihan stok. Pengendalian persediaan bahan baku yang tepat dapat membantu menekan biaya-biaya operasional seminimal mungkin sehingga kinerja dan keuntungan perusahaan lebih optimal. Oleh karena itu, pengendalian persediaan bahan baku dibutuhkan sebab perusahaan harus memiliki persediaan yang seoptimal mungkin. Untuk menentukan kebijakan penyediaan bahan baku yang tepat dalam arti tidak mengganggu proses produksi dapat digunakan metode EOQ.

\section{EKSPERIMEN}

Pada penelitian ini, pengumpulan data dilakukan pada bulan April sampai Mei 2021 di CV Tirta Makmur. Data yang dikumpulkan adalah seperti berikut :

1. Data pembelian bahan baku cup $120 \mathrm{~mL}$ yang dilakukan oleh CV Tirta Makmur setiap bulannya dari bulan April 2020 sampai Maret 2021.

2. Data pemakaian bahan baku cup $120 \mathrm{~mL}$ yang dilakukan oleh CV Tirta Makmur untuk kepentingan prosuksi setiap bulannya dari bulan April 2020 sampai Maret 2021.

3. Rincian biaya yang dikeluarkan oleh CV Tirta Makmur setiap dilakukannya pemesanan cup $120 \mathrm{~mL}$.

4. Rincian biaya yang dikeluarkan oleh CV Tirta Makmur untuk penyimpanan cup $120 \mathrm{~mL}$.

5. Harga beli bahan baku cup $120 \mathrm{~mL}$. 
Alur penelitian dalam studi ini disajikan dalam Gambar 1.

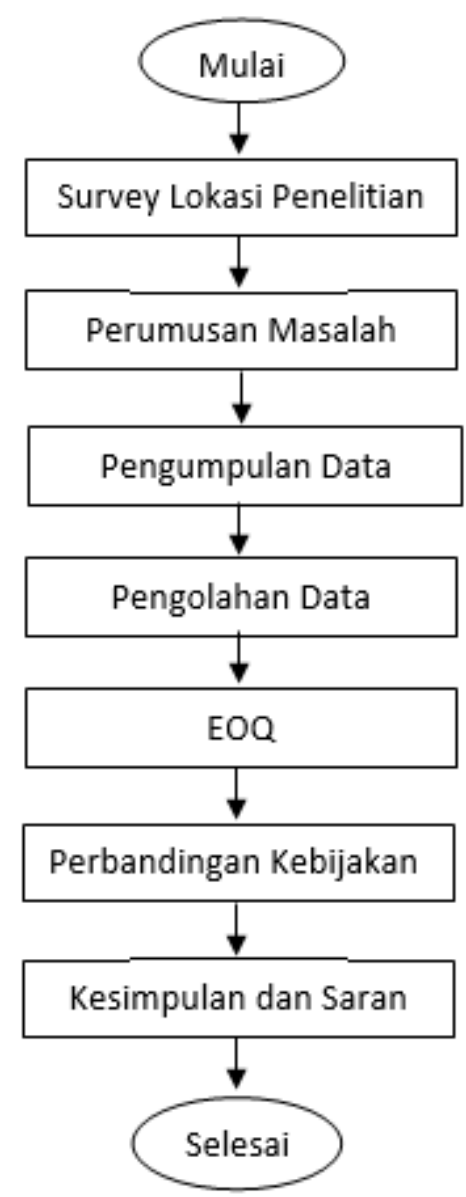

Gambar 1. Flow chart untuk penelitian

\section{Desain Penelitian}

Penelitian ini didesain sebagai penelitian deskriptif yang bersifat kuantitatif karena penelitian ini berdasarkan pada objek penelitian yang dilakukan dengan mengumpulkan keterangan-keterangan data perusahaan yang dikaitkan dengan data yang diperlukan didalam pelaksanaan penelitian. Penelitian ini menggunakan penerapan dari EOQ untuk mencari nilai optimal terhadap persediaan bahan baku kemasan cup $120 \mathrm{~mL}$ yang merupakan objek dari penelitian. Hasil yang diperoleh akan dibandingkan dengan kebijakan perusahaan yang selama ini telah dijalankan, yaitu pemesanan akan dilakukan ketika persediaan cup $120 \mathrm{~mL}$ telah mencapai batas yang telah ditetapkan sekitar 5000 karton atau 225.000 pcs. Setelah dilakukan perbandingan, maka suatu kesimpulan dapat diambil, yaitu bagaimana pengoptimalan persediaan cup 120 $\mathrm{mL}$ di CV Tirta Makmur. Pengambilan data dilakukan secara langsung melalui proses wawancara dan melalui laporan-laporan dari bagian PPIC (Production Planning and Inventory Control).

\section{Metode}

Penelitian dilakukan di CV Tirta Makmur yang merupakan perusahaan air minum dalam kemasan. Dengan data yang telah diperoleh, perhitungan optimalisasi persediaan bahan baku kemasan cup $120 \mathrm{~mL}$ dilakukan dengan menggunakan metode EOQ. Metode EOQ memiliki beberapa asumsi yang harus dipenuhi terlebih dahulu oleh data yang akan digunakan agar EOQ dapat digunakan. Asumsi-asumsi tersebut antara lain :

a. Produk yang dipesan dan yang akan disimpan merupakan produk yang sejenis (homogeny)

b. Permintaan akan produk adalah konstan, seragam dan diketahui (deterministik)

c. Harga per unit produk adalah konstan

d. Biayar penyimpanan per unit per tahun adalah konstan

e. Biaya pemesanan perpesanan adalah konstan

f. Tidak ada discount pembelian

g. Barang yang dipesan tidak mengalami kerusahakan

h. Barang yang dipesan segera tersedia (tidak diijinkan back order). 
Data yang diamati hanya terkhusus pada cup $120 \mathrm{~mL}$, rata-rata permintaan per periode diketahui, biaya pemesanan diketahui konstan, biaya penyimpanan per tahun diketahui, serta pengamatan diketahui bahwa tidak ada discount dan tidak diperbolehkan adanya backorder/stockout. Berdasarkan data yang diperoleh, model EOQ deterministik klasik (sederhana) cocok digunakan untuk menyelesaikan permasalahan persediaan cup $120 \mathrm{~mL}$. Penyelesaian dengan menggunakan model EOQ membutuhkan beberapa parameter yaitu

K : Biaya pemesanan (Ordering Cost) / pemesanan,

Ch : Biaya penyimpanan (Holding Cost) / tahun,

$p \quad$ : Biaya pemesanan / pcs cup,

D : Jumlah permintaan / tahun,

$q \quad$ : Jumlah pemesanan awal (pcs),

$q^{*} \quad$ : Jumlah pemesanan optimal (pcs),

$T \quad$ : Waktu yang diperlukan untuk satu siklus,

$f \quad$ : Frekuensi pemesanan / tahun,

$T C(q)$ : Total biaya persediaan satu siklus,

$C(q) \quad$ :Total biaya persediaan selama satu tahun.

\section{Komponen Pembentuk Inventory Cup $120 \mathrm{~mL}$}

Sesuai dengan pernyataan di atas, beberapa komponen dalam menyelesaikan model EOQ dibutuhkan. Dari data yang telah diperoleh, jumlah pemesanan $(q)$ dalam setahun tercatat sebanyak 39.793.280 pcs (pieces), dimana pemesanan dilakukan setiap sisa persediaan sebelum produksi menyentuh jumlah sekitar 5.000 karton atau setara dengan sekitar 225.000 pcs. Biaya pemesanan $(K)$ yang dikeluarkan oleh CV Tirta Makmur dalam pemesanan cup $120 \mathrm{~mL}$ yaitu sebesar Rp 46.000 per pemesanan, dimana angka ini diperoleh dari 2 karyawan yang melakukan bongkar muatan dikalikan 25 hari kerja dibagi dengan 16 kali kemungkinan kedatangan barang yang dipesan. Jumlah permintaan per tahun $(D)$ tercatat sebanyak 38.042.064 pcs, dengan rata-rata permintaan harian sebanyak 104.225 pcs dan rata-rata permintaan per bulan sebanyak 3.170 .172 pcs. Biaya pembelian $(p)$ per cup secara konstan sebesar Rp 102 per pcs, dengan jumlah biaya yang dikeluarkan oleh CV Tirta Makmur dalam setahun untuk pembelian yaitu sebesar Rp 4.058.914.560,00. Biaya penyimpanan $(C h)$ yang dikeluarkan dalam setahun sebesar Rp. 0,01 per pcs. Beberapa komponen lain yang diperlukan yaitu termasuk pemesanan optimal $\left(q^{*}\right)$, tenggang waktu antara pembelian sebelumnya dengan yang selanjutnya $(T)$ dan frekuensi pemesanan selama satu bulan $(f)$.

\section{HASIL DAN DISKUSI}

CV Tirta Makmur memiliki permintaan terbanyak pada produk cup $120 \mathrm{~mL}$. Setiap bulan, permintaan untuk cup $120 \mathrm{~mL}$ selalu ada dan tidak pernah kosong, berbeda dengan beberapa produk lain yang bahkan pada bulan tertentu tidak diproduksi sama sekali karena tidak ada permintaan. Ini adalah penting bagi CV Tirta Makmur untuk menyiapkan strategi yang baik dalam persiapan produksi setiap produknya, terutama cup $120 \mathrm{~mL}$ karena merupakan produk yang paling banyak permintaan. Metode EOQ akan dapat membantu perusahaan dalam persiapan strategi produksi karena akan memberikan hasil yang dapat digunakan perusahaan sebagai tolak ukur dalam pemesanan bahan baku. Perhitungan dengan metode EOQ dalam penelitian ini adalah sebagai berikut.

Hasil

Berdasarkan data, berikut ini adalah nilai-nilai yang diperoleh :

D : 38.042 .064

$K \quad:$ Rp 46.000

$p \quad:$ Rp 102 per pcs

Ch : Rp 0,01

Permasalahan persediaan cup $120 \mathrm{~mL}$ diselesaikan dengan menggunakan EOQ yaitu

- Jumlah pemesanan optimal:

$$
\begin{aligned}
q^{*} & =\sqrt{\frac{2 \times K \times D}{C_{h}}}=\sqrt{\frac{2 \times 46.000 \times 38.042 .064}{0,01}} \\
& =18.707 .939,19 \approx 18.707 .939 p c s
\end{aligned}
$$


Jadi, jumlah pemesanan optimal cup $120 \mathrm{~mL}$ setiap kali dilakukan pemesanan yaitu sebanyak 18.707 .939 pcs.

- Periode pemesanan:

$T^{*}=\frac{q^{*}}{D}=\frac{18.707 .939}{38.042 .064}=0,491769826$ tahun $=0,491769826 \times 12$ bulan $=5,901237911$

$\approx 6$ bulan

Jadi, periode pemesanan cup $120 \mathrm{~mL}$ dalam satu tahun adalah setiap 6 bulan, artinya sekitar 180 hari sekali akan dilakukan pemesanan.

- Frekuensi pemesanan:

$f^{*}=\frac{1}{T^{*}}=\frac{D}{q^{*}}=\frac{38.042 .064}{18.707 .939}=2,033471651 \approx 2$ kali

Jadi, pemesanan cup $120 \mathrm{~mL}$ dilakukan 2 kali dalam kurun waktu satu tahun untuk menghindari kekurangan persediaan.

- Total biaya setiap kali pemesanan:

$$
\begin{aligned}
T C\left(q^{*}\right) & =K+p \times q^{*}+\frac{q^{*}}{2} \times C_{h} \times T^{*} \\
& =46.000+102 \times 18.707 .939+\frac{18.707 .939}{2} \times 0,01 \times \frac{18.707 .939}{38.042 .064} \\
& =1.908 .301 .778
\end{aligned}
$$

Jadi, total biaya setiap kali dilakukan pemesanan cup $120 \mathrm{~mL}$ yaitu sebesar Rp. 1.908.301.778,00.

- Total biaya setahun:

$$
\begin{aligned}
C\left(q^{*}\right) & =\frac{K x D}{q^{*}}+p \times D \times \frac{q^{*}}{2} \times C_{h}=\left(K+p \times \frac{q^{*}}{2} \times C_{h} \times T^{*}\right) \times f=T C\left(q^{*}\right) \times f \\
& =1.908 .301 .778 \times 2=3.816 .603 .556
\end{aligned}
$$

Jadi, total seluruh biaya yang harus dikeluarkan oleh CV. Tirta Makmur selama satu tahun untuk cup 120 $\mathrm{mL}$ dengan menggunakan metode EOQ yaitu sebesar Rp. 3.816.603.556,00.

Selanjutnya hasil perhitungan dengan metode EOQ dibandingkan dengan kebijakan CV Tirta Makmur. Kebijakan dari CV Tirta Makmur adalah sebagai berikut :

- Jumlah pemesanan

CV Tirta Makmur dalam pemesanan cup $120 \mathrm{~mL}$ selalu melakukan pemesanan ketika persediaan cup 120 $\mathrm{mL}$ menyentuh batas yang telah ditetapkan oleh perusahaan, yaitu sekitar 5.000 karton atau 225.000 pcs cup $120 \mathrm{~mL}$. Jumlah pemesanan disesuaikan oleh kebutuhan dan telah tertera dalam setahun terakhir pada Tabel 1, yaitu 3.316.106 per bulan.

- Periode pemesanan

Periode pemesanan pada CV Tirta Makmur dilakukan setidaknya setiap minggu pasti dilakukan pemesanan cup $120 \mathrm{~mL}$ secara konstan dalam setahun. Periode pemesanan yaitu 48 kali setahun atau dengan kata lain secara rata-rata ada 4 kali pemesanan dalam sebulan, artinya sekitar 7 hari sekali dilakukan pemesanan.

- Frekuensi pemesanan

Frekuensi pemesanan cup $120 \mathrm{~mL}$ sesuai kebijakan dari CV Tirta Makmur yaitu menyesuaikan dengan kebutuhan produksi.

$f=\frac{\text { jumlah pemesanan } 1 \text { tahun }}{\text { jumlah pemesanan } 1 \text { periode }}=\frac{39.793 .280}{829.026,5}=48,00000965 \approx 48$

Jadi, pemesanan cup $120 \mathrm{~mL}$ dilakukan 48 kali dalam setahun.

- Total biaya setiap kali pemesanan

Perhitungan terhadap total biaya setiap kali pemesanan dilakukan untuk cup $120 \mathrm{~mL}$ di CV Tirta Makmur dilakukan seperti berikut ini.

$$
\begin{aligned}
T C\left(q^{*}\right) & =K+p \times q+\frac{q}{2} \times C_{h} \times T \\
& =46.000+102 \times 3.316 .106+\frac{3.316 .106}{2} \times 0,01 \times \frac{829.026,5}{39.793 .280} \\
& =338.289 .157
\end{aligned}
$$

Jadi, total biaya setiap kali pemesanan menurut kebijakan CV Tirta Makmur adalah Rp. 338.289.157,00. 
- Total biaya setahun

$$
\begin{aligned}
C(q) & =\frac{K x D}{q}+p \times D \times \frac{q}{2} \times C_{h}=\left(K+p \times \frac{q}{2} \times C_{h} \times T\right) \times f=T C(q) \times f \\
& =338.289 .157 \times 48 \\
& =16.237 .879 .557
\end{aligned}
$$

Jadi, total seluruh biaya yang harus dikeluarkan oleh CV Tirta Makmur selama satu tahun untuk cup 120 $\mathrm{mL}$ berdasarkan kebijakan perusahaan yaitu sebesar Rp. 16.237.879.557,00.

Berdasarkan hasil perhitungan di atas, perhitungan menggunakan metode EOQ maupun kebijakan perusahaan dalam persediaan cup $120 \mathrm{~mL}$ dibandingkan. Untuk lebih jelas, hasil perbandingan disajikan dalam Tabel 2.

Tabel 2. Tabel perbandingan hasil

\begin{tabular}{lll}
\hline Parameter & Metode EOQ & Kebijakan Perusahaan \\
\hline Pembelian per periode & 18.707 .939 pcs & 3.316 .106 pcs \\
Periode Pemesanan & 180 hari & 7 hari \\
Frekuensi Pemesanan & 2 kali & 48 kali \\
Total Biaya Sekali Pesan & Rp. $1.908 .301 .778,00$ & Rp. $338.289 .157,00$ \\
Total Biaya Satu Tahun & Rp. 3.816.603.556,00 & Rp. $16.237 .879 .557,00$ \\
\hline
\end{tabular}

Tabel 2 memperlihatkan bahwa perhitungan total biaya satu tahun dengan menggunakan metode EOQ yaitu sebesar Rp. 3.816.603.556,00. Pembelian per periode secara optimal yaitu sebesar 18.707.939 pcs setiap kali dilakukan pemesanan, dengan periode pemesanan 180 hari sekali atau dengan kata lain berfrekuensi 2 kali pemesanan dalam satu tahun. Setiap pemesanan dilakukan akan mengeluarkan biaya sebesar Rp. 1.908.301.778,00. Ini berbeda dengan kebijakan perusahaan yang terlihat lebih banyak pengeluaran per tahunnya untuk pemesanan cup 120 mL, yaitu mencapai sebesar Rp. 16.237.879.557,00.

Perhitungan terhadap perbedaan keuntungan dengan menggunakan metode EOQ yaitu sebagai berikut :

$$
C(q)-C\left(q^{*}\right)=\operatorname{Rp} 16.237 .879 .557-\operatorname{Rp} 3.816 .603 .556=\operatorname{Rp} 12.421 .276 .001
$$

Perbedaan keuntungan yang diperoleh dengan menggunakan metode EOQ dibandingkan dengan kebijakan perusahaan yaitu sebesar Rp 12.421.276.001,00. Total biaya yang dikeluarkan per tahun sebesar $\frac{3.816 .603 .556}{16.237 .879 .557} \times 100 \%=23,5 \%$, yang merupakan persentase dari metode EOQ dalam mengoptimalkan biaya pemesanan. Jadi, metode EOQ terbukti dapat secara optimal meminimalkan biaya pemesanan cup $120 \mathrm{~mL}$ di CV Tirta Makmur dengan persentase hingga sebesar 23,5\%.

Nilai persentase yang diperoleh dari hasil perhitungan termasuk nilai yang besar, terbukti dengan data yang didapatkan dari CV Tirta Makmur bahwa pemesanan dan pemakaian terkadang memiliki perbedaan yang lumayan besar baik itu jumlah yang dipesan lebih besar maupun jumlah yang diperlukan yang lebih besar. Dengan perhitungan yang diperoleh menggunakan metode EOQ, studi ini dapat menjadi pertimbangan bagi pihak CV Tirta Makmur dalam melakukan pemesanan bahan baku cup $120 \mathrm{~mL}$.

\section{Diskusi}

Hasil yang telah diperoleh dengan perhitungan menggunakan metode EOQ, jika dibandingkan dengan kebijakan perusahaan, dapat menekan biaya pengeluaran untuk pemesanan bahan baku. Ini berarti bahwa hasil yang diperoleh dengan menggunakan metode EOQ dapat menjadi pertimbangan bagi perusahaan guna mengoptimalkan biaya pemesanan. Hasil ini juga diperkuat oleh beberapa penelitian terlebih dahulu yang telah dilakukan oleh Andari \& Solahuddin (2019) dalam penelitian yang berjudul "Analisis Pengendalian Persediaan untuk Meminimalisasi Biaya pada Bahan Kemasan Botol $70 \mathrm{~mL} 8 \mathrm{Gram}$ di Pt. Milko Beverage Industry Bogor" dengan menggunakan metode EOQ dan perbandingan dengan LFL (Lot For Lot). Penelitian tersebut memberikan hasil bahwa metode EOQ dapat menekan harga pembelian bahan baku. Penelitian lain dilaksanakan oleh Lahu et al. (2017) dalam artikel berjudul "Analisis Pengendalian Persediaan Bahan Baku Guna Meminimalkan Biaya Persediaan pada Dunkin Donuts Manado" dengan menggunakan metode EOQ. Studi tersebut memperoleh hasil bahwa jumlah pemesanan dan frekuensi pemesanan mengalami penurunan, dimana hal ini dapat menyebabkan penghematan biaya persediaan dan tidak terjadinya kelebihan bahan baku persediaan. Sementara itu, Yaqin (2018) dalam penelitiannya yang berjudul "Pengendalian Persediaan Bahan Baku Kedelai pada UD. Karya Jaya Batu" juga memaparkan hasil bahwa perhitungan EOQ nilai Total Inventory Cost (TIC) lebih kecil dibandingkan dengan TIC menggunakan perhitungan kebijakan perusahaan. Penelitian Putri et al. (2020) yang berjudul "Analisis Pengendalian 
Persediaan Bahan Baku Rotan Terhadap Kelancaran Proses Produksi pada CV Home Fashions Indonesia Cirebon" menjelaskan bahwa metode EOQ dapat menentukan jumlah pembelian bahan baku yang optimal dan ekonomis dengan lebih terstruktur karena jumlah pembelian bahan baku dipastikan konstan.

\section{KESIMPULAN}

Studi ini telah melakukan perhitungan dengan menggunakan metode EOQ dalam mengatasi permasalahan pengendalian persediaan cup $120 \mathrm{~mL}$ di CV Tirta Makmur. Kesimpulan yang diperoleh yaitu bahwa metode EOQ dapat mengatasi permasalahan pengendalian persediaan bahan baku cup $120 \mathrm{~mL}$ di CV Tirta Makmur. Metode tersebut dapat memberikan perbedaan keuntungan hingga 23,5 \% dibandingkan dengan menggunakan kebijakan perusahaan. Berdasarkan hasil yang didapatkan, studi perhitungan dengan menggunakan metode EOQ ini dapat menjadi bahan pertimbangan bagi perusahaan CV Tirta Makmur dalam melakukan pemesanan bahan baku cup $120 \mathrm{~mL}$. Menggunakan metode EOQ, perusahaan dapat menyesuaikan jumlah pemesanan optimal, priode pemesanan, frekuensi, dan biaya yang dikeluarkan guna meminimumkan biaya yang keluar. Dengan adanya hasil perhitungan metode EOQ, ini dapat mengatasi permasalahan persediaan bahan baku agar tidak terjadi kehabisan stok bahan baku maupun pengeluaran yang berlebihan dalam pemesanan sehingga perusahaan dapat terhindar dari kerugian.

\section{DAFTAR PUSTAKA}

Andari, T. T., \& Solahuddin, A. (2019). Analisis Pengendalian Persediaan Untuk Meminimalisasi Biaya Pada Bahan Kemasan Botol 70 Ml 8 Gram Di Pt. Milko Beverage Industry Bogor. Jurnal Visionida, 4(2), 54. https://doi.org/10.30997/jvs.v4i2.1532

Febilia, C. M. (2016). Evaluasi Manajemen Persediaan Pupuk PT. ABC Menggunakan Metode EOQ.

Kristyaningrum, E. Y., Ekowati, T., \& Setiyadi, A. (2018). Efisiensi Persediaan Beras Pada Perusahaan Umum Bulog Divisi Regional Jawa Timur. Agro Ekonomi, 27(1), 38. https://doi.org/10.22146/jae.32793

Kurniawati, N. (n.d.). Pengendalian Persediaan Bahan Baku Dalam Mengefisiensikan Biaya Persediaan Dengan Metode Linear Programming Nia Kurniawati Prodi S1. Teknik Sipil , Jurusan Teknik Sipil, Fakultas Teknik , Universitas Negeri Surabaya Email : niakurniawati@mhs.unesa.ac.id. 1, 1-12.

Lahu, E. P., Sumarauw, J. S. B., Ekonomi, F., Manajemen, J., Sam, U., Manado, R., \& Belakang, L. (2017). Analisis Pengendalian Persediaan Bahan Baku Guna Meminimalkan Biaya Persediaan Pada Dunkin Donuts Manado. Jurnal EMBA: Jurnal Riset Ekonomi, Manajemen, Bisnis Dan Akuntansi, 5(3), 41754184. https://doi.org/10.35794/emba.v5i3.18394

Putri, C. A., Hamdah, D. F. L., \& Pansuri, C. H. (2020). Analisis Pengendalian Persediaan Bahan Baku Rotan Terhadap Kelancaran Proses Produksi Pada CV. Home Fashions Indonesia Cirebon. Jurnal Wacana Ekonomi, 19(3), 167. https://doi.org/10.52434/jwe.v19i3.1024

Santoso, B. (2009). Analisis Pengendalian Persediaan Air Mineral Menggunakan Metode EOQ (Studi Kasus pada Agen Tirta Indah). 4-68.

Sofyan, D. K. (2017). Analisis Persediaan Bahan Baku Buah Kelapa Sawit pada PT . Bahari Dwikencana Lestari. Industrial Engineering Journal, 6(1), 50-56.

Vikramul Ainum Na'im, M. (2016). Analisis Persediaan Bahan Baku Dengan Menggunakan Metode Economic Order Quantity (EOQ) Terhadap Kelancaran Produksi Pada Industri Pembuatan Tempe Al-Hidayah Gondanglegi Prambon Nganjuk. Universitas Nusantara PGRI Kediri, 1-16.

Yaqin, N. (2018). Pengendalian Persediaan Bahan Baku Kedelai pada UD Karya Jaya Batu. Jurnal Agregat, 7(1), 1-11. 